\title{
DISTRIBUSI DAN BIOLOGI REPRODUKSI UDANG GALAH (Macrobrachium rosenbergii) DI SUNGAI MUSI SUMATERA SELATAN
}

\author{
Agus Djoko Utomo") dan Azwar Said")
}

\begin{abstract}
ABSTRAK
Sungai Musi merupakan sungai terbesar di Sumatera Selatan mempunyai ekosistem yang kompleks seperti rawa banjiran, pasang surut, dan air deras. Habitat tersebut banyak di huni oleh organisme air sepert ikan dan udang. Siklus udang galah memerlukan dua habitat yaitu saat dewasa berada di air tawar sedangkan saat larva memerlukan air payau. Penelitian bertujuan untuk mendapatkan data distribusi udang galah di Sungai Musi berdasarkan ukuran, kematangan gonad, waktu, dan tempat. Penelitian dilakukan pada bulan Juni 2002 hingga Desember 2002, dengan memilih stasiun yang mewakili hilir, tengah, dan hulu yaitu Makati, Mariana, Gandus, Sekayu, Rawas, dan Tebing Tinggi. Parameter yang diamati meliputi sebaran ukuran, tingkat kematangan gonad, fekunditas, dan kualitas air. Hasil penelitian menunjukkan bahwa zona bagian hilir terdapat berbagai macam ukuran udang dengan kisaran panjang total $5-30 \mathrm{~cm}$, zona bagian tengah di Stasiun Sekayu didominasi pada bulan Juni oleh ukuran 15-20 cm sedang pada bulan September didominasi oleh ukuran $10-15 \mathrm{~cm}$. Zona bagian tengah di Stasiun Muara Rawas didominasi oleh ukuran 20$25 \mathrm{~cm}$. Zona bagian hulu sungai yang berair deras jarang ditemukan udang galah. Udang galah dapat memijah sepanjang tahun, fekunditas individu pada ukuran $15-30 \mathrm{~cm}$ berkisar antara $28.700-59.700$ butir telur. Zona bagian hilir sungai terdapat induk yang sudah dibuahi dari berbagai tingkat kematangan gonad dengan warna gonad kuning, coklat, dan abu-abu. Zona bagian tengah terdapat induk yang sudah dibuahi yang didominasi oleh gonad yang berwarna kuning dan coklat.
\end{abstract}

ABSTRACT: Distribution and reproductive biology of prawn (Macrobrachium rosenbergii) at Musi river South Sumatera. By: Agus Djoko Utomo, and Azwar Said

Musi river is the biggest river in South Sumatera. There are complex ecosystem such as flood plain, tide and fast current water body. That habitats many organism such as fishes and prawn. Life cycle of prawn need two habitats, during larvae live in brackish water after pasca larvae live in fresh water. The objective of reseaerch to get distribution of prawn base on size, reproduction, season and habitats. The research were conducted on June 2002 to December 2002. Some station were choosen in consectively from down stream to up stream; Makati, Mariana, Gandus, Sekayu, Muara Rawas, and Tebing Tinggi. Some parameters were taken; total length of prawn, gonad maturity, fecundity, and water-quality. The results shown that total length range on down stream were $5-30 \mathrm{~cm}$. Sekayu station on June were dominated by $15-20 \mathrm{~cm}$ but on September were dominated by $10-15 \mathrm{~cm}$. Musi Rawas station were dominated by $20-25 \mathrm{~cm}$. Up stream zone with fast current very rarely prawn. Prawn can spent as along as the year, female with size $15-30 \mathrm{~cm}$ have fecundity 28.700-59.700 eggs. Barried gonad on down stream more variation, they are yellow-orange, brawn, and grey. Bewrried gonad on middle stream were dominated by yellow-orange and brawn.

Key Word: $\quad$ distribution, reproductive biology, prawn, river

\section{PENDAHULUAN}

Sungai Musi merupakan sungai terbesar di Sumatera Selatan. Di bagian tengah sungai (midle stream) banyak terdapat habitat rawa banjiran (flood plain) dan di bagian hilirnya (down stream) merupakan perairan yang dipengaruhi pasang surut. Habitat seperti tersebut merupakan tempat kehidupan udang galah. Siklus udang galah memerlukan dua habitat yaitu habitat air tawar dan payau. Pada saat dewasa dan pemijahan, udang galah memerlukan habitat air tawar. Sedangkan pada saat larva udang tersebut memerlukan air payau (Djajadiredja et. al., 1980).

Udang galah merupakan jenis udang galah air tawar yang berukuran besar. Ciri khusus udang galah yaitu: bentuk rostrum yang memanjang seperti pedang, pada rostrum bagian atas terdapat 11-13 gerigi sedangkan bagian bawah 8-14 gerigi. Pada bagian dada terdapat lima pasang kaki jalan (periopoda), pada bagian badan (abdomen) terdapat lima ruas yang masing-masing dilengkapi dengan kaki renang (pleiopoda). Pada udang galah betina, diantara kaki renang agak melebar membentuk suatu ruangan untuk mengerami telur (broodchamber). Udang galah jantan yang dewasa, pada kaki jalan kedua ukurannya panjang dan besar jika dibanding dengan kaki yang lain, panjangnya dapat mencapai 1,5 kali panjang badan. Sedangkan pada yang betina perbedaan ukuran kaki tersebut tidak mencolok (Hadie \& Hadie 1993; Djajadiredja et. al., 1980).

Udang galah merupakan komoditas eksport dan konsumsi domistik, untuk memenuhi kebutuhan tersebut kegiatan penangkapan sangat intensif. Alat tangkap yang digunakan untuk menangkap udang

\footnotetext{
") Peneliti pada Balai Riset Perikanan Perairan Umum Palembang
} 
galah yaitu: bengkirai bilah (pot traps), empang lulung (barrier traps), pancing, langgian (scoop net), tuguk (filtering device) (Arifin, 1978; Hoggarth \& Utomo, 1994). Menurut Utomo (2000) tuguk merupakan jenis alat tangkap yang membahayakan kelestarian sumber daya perikanan karena cara operasinya menghadang udang yang sedang melakukan ruaya pemijahan dan alat tersebut tidak selektif. Di perairan Lubuk Lampam hasil tangkapan udang galah tiap tahun mengalami penurunan rata-rata $12,5 \%$ (Utomo, 1997).

Kelangsungan hidup udang galah di perairan merupakan kunci penting dalam mempertahankan populasinya. Untuk itu daur hidup udang galah di suatu perairan harus diketahui untuk kemudian diselamatkan baik dari gangguan alat tangkap maupun gangguan lainnya. Data yang berhubungan dengan daur hidup udang yaitu distribusi biologi reproduksi dan ruaya. Penelitian bertujuan untuk mendapatkan data distribusi berdasarkan ukuran dan kematangan gonad udang galah di Sungai Musi. Informasi tersebut diharapkan berguna bagi pengelolaan sumber daya udang galah di Sungai Musi.

\section{BAHAN DAN METODE}

Pengumpulan Data Distribusi dan Hasil
Tangkapan

Pengambilan contoh udang galah dilakukan tiap bulan pada lokasi yang sudah ditentukan. Lokasi yang diambil yaitu perairan yang diperkirakan menjadi lintasan udang galah mulai dari bagian hulu hingga hilir sungai. Stasiun pengambilan contoh bagian hilir sungai (down stream) yaitu: Makati, Mariana, dan Gandus. Stasiun bagian tengah (middle stream) yaitu Sekayu dan Rawas, sedangkan bagian hulu sungai yaitu Tebing tinggi. Contoh udang diambil dari hasil tangkapan nelayan terutama dari alat yang tidak selektif yaitu belat (set net) dan bengkirai bilah (pot traps). Udang diukur panjang $(\mathrm{cm})$, berat (gram), dan diperiksa jenis kelaminnya. Hasil tangkapan udang galah dicatat berdasarkan jenis alat, jumlah alat, lokasi, dan waktu. Sampling udang galah pada lokasi tersebut dilakukan tiap bulan mulai bulan Juni 2002 hingga Desember 2002

\section{Pengamatan Tingkat Kematangan Gonad}

Perkembangan tingkat kematangan gonad, diamati secara langsung di lapangan setiap bulan. Udang diambil dari hasil tangkapan nelayan, diukur panjang total $(\mathrm{cm})$ dan bobotnya (gram), dicatat lokasi dan waktu tertangkapnya. Bagi udang yang sudah melakukan pemijahan, pengamatan gonad dilakukan pada ruang pengeramannya (broodchamber) yang terletak di antara kaki renang.

Tingkat kematangan gonad setelah terjadi pembuahan berdasarkan Nikolsky dalam Mantel (1983) yaitu, apabila pada ruang pengeram terdapat telur berwarna kuning muda berarti baru melakukan pemijahan, kemudian tingkat selanjutnya berubah menjadi jingga, kecoklatan, dan yang terakhir keabuabuan pertanda telur tersebut sudah siap untuk menetas.

\section{Pengamatan Data Kualitas Air}

Sebagai data pendukung dilakukan pemeriksaan kualitas air yang diperkirakan berpengaruh terhadap pola sebaran udang galah yaitu:

1. Salinitas.

Udang yang akan melakukan penetasan telur dan larva udang galah akan mencari air payau

2. Oksigen terlarut.

Kadar oksigen di perairan rawa banjiran sering mengalami penurunan, karena dipakai proses dekomposis bahan organik.

3. Karbon dioksid.

Kadar karbon dioksid sering mengalami kenaikan karena hasil proses dekomposisi bahan organik.

4. $\mathrm{PH}$.

Keasaman perairan rawa sering mengalami perubahan karena pengaruh sisa-sisa proses dekomposisi.

5. DHL.

Daya hantar listrik dari garam-garam yang terlarut sangat bervariasi, terutama antara perubahan air payau dan air tawar.

\section{Analisis Data}

Data hasil pengambilan contoh ukuran udang, jenis kelamin dan kematangan gonad pada tiap lokasi dianalisis secara deskriptif berdasarkan tabulasi data dan grafik histogram. Dengan demikian diketahui distribusi udang galah di Sungai Musi berdasarkan ukuran, tingkat kematangan gonad, waktu, dan tempat dapat diketahui.

\section{HASIL DAN BAHASAN}

\section{Sebaran Ukuran Udang Galah (Macrobrachium rosenbergii)}

Udang galah dapat ditemukán di sepanjang Sungai Musi mulai dari hilir hingga bagian hulu sungai, namun sebaran ukuran udang galah mempunyai perbedaan masing-masing zona (hulu, tengah, dan hilir). Di bagian hilir sungai, sebaran ukuran udang merata mulai dari ukuran kecil (nilai tengah panjang total $5 \mathrm{~cm}$ ) hingga ukuran besar (nilai tengah panjang total $30 \mathrm{~cm}$ ). Pada setiap kali sampling (mulai bulan Juni hingga Desember 2002) ukuran tersebut selalu ada dan frekuensi yang paling banyak terdapat pada ukuran $10-15 \mathrm{~cm}$. Hal tersebut 
disebabkan bahwa bagian hilir sungai merupakan tempat penetasan udang galah. Induk udang yang mau menetaskan telur cenderung pergi ke hilir sungai untuk mencari air payau sebagai media penetasan telur dan larva udang galah (Djadjadiradja et. al., 1980; Hadie \& Hadie, 1993; Utomo, 2001). Tiga stasiun pengambilan contoh di bagian hilir sungai yaitu Makati, Mariana, dan Gandus menunjukan bahwa dari ketiga lokasi tersebut tidak kelihatan perbedaan sebaran ukuran udang galah pada setiap kali sampling, karena tiga lokasi tersebut masih merupakan tempat udang galah mulai dari yang berukuran kecil hingga yang berukuran besar.

Stasiun pengambilan contoh di bagian tengah yaitu daerah Sekayu menunjukkan bahwa pada bulan Juni 2002 ukuran udang galah yang mendominasi yaitu $15-20 \mathrm{~cm}$. Sedangkan pada bulan September 2002 ukuran udang yang mendominasi yaitu $10 \mathrm{~cm}$ bahkan ada ukuran $5 \mathrm{~cm}$ walaupun jumlahnya tidak banyak, hal ini disebabkan pada saat itu ukuran udang yang kecil $(5 \mathrm{~cm}$ dan $10 \mathrm{~cm}$ ) mulai masuk di bagian tengah (Sekayu) dari hilir sungai. Sedangkan stasiun pengambilan contoh di bagian tengah yang lain yaitu Muara Rawas menunjukkan bahwa ukuran udang galah didominasi udang yang berukuran besar yaitu panjang total $20 \mathrm{~cm}$ dan $25 \mathrm{~cm}$. Pada bulan Nopember udang galah yang berukuran $10 \mathrm{~cm}$ mulai ada walaupun jumlahnya tidak begitu banyak, hal tersebut disebabkan karena udang yang berukuran kecil $10 \mathrm{~cm}$ mulai masuk ke perairan Muara Rawas dari hilir sungai. Di perairan Musi Rawas tidak diketemukan ukuran udang galah yang berukuran panjang total $5 \mathrm{~cm}$ (lihat gambar 1).

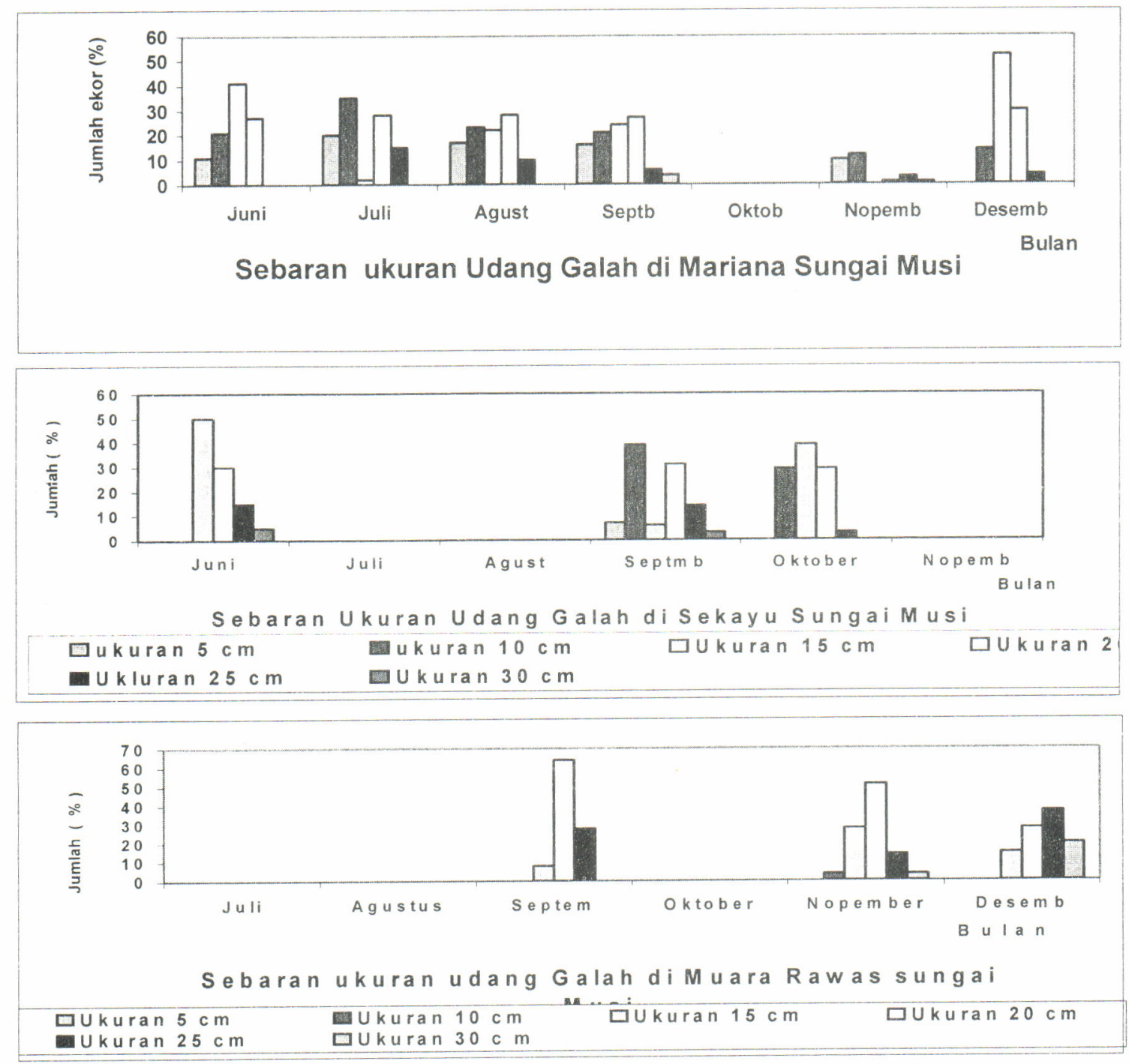

Gambar 1. Sebaran ukuran udang galah (Macrobrachium rosenbergii) di sungai Musi Sumatera Selatan. 
Di perairan Muara Kelingi yaitu arah hulu dari Muara Rawas, menurut informasi dari masyarakat setempat ukuran udang galah yang tertangkap biasanya lebih dari $20 \mathrm{~cm}$. Kegiatan penangkapan udang galah di perairan tersebut hanya merupakan sambilan dengan alat tangkap Jala. Sedangkan di perairan Tebing Tinggi yaitu lebih ke hulu dari muara Kelingi, perairannya berarus deras dan berbatu, menurut informasi dari masyarakat setempat hampir tidak pernah tertangkap udang galah.

\section{Kematangan Gonad}

Di bagian hilir sungai (stasiun pengamatan: Makati, Mariana, dan Gandus) terdapat induk udang galah yang sudah dibuahi pada berbagai macam tingkat kematangan gonad yaitu gonad warna kuning jingga (baru dibuahi), warna coklat (sudah lebih berkembang), dan warna abu-abu (sudah hampir menetas). Contoh udang galah dengan gonad yang sudah dibuahi di bagian hilir lebih mudah didapatkan bila dibandingkan dengan zona lain yaitu tengah dan hulu. Hal tersebut disebabkan induk udang galah dari berbagai tempat yang akan menetaskan telur cenderung pergi ke hilir untuk menetaskan telurnya di perairan yang bersalinitas, sehingga di bagian hilir sungai induk udang galah yang sudah dibuahi lebih beragam (gambar 2 ).

Di bagian tengah sungai (stasiun pengamatan Sekayu dan Rawas) yang jauh dari pengaruh pasang surut air laut, kondisi ekologisnya banyak dipengaruhi oleh daerah rawa banjiran. Pada saat musim kemarau di daerah ini sulit untuk mendapatkan sampel udang galah bila dibandingkan di bagian hilir sungai. Gonad yang sudah dibuahi kebanyakan berwarna kuning jingga, dan coklat, sedangkan yang warna abu-abu hanya ada pada bulan Desember. Masa inkubasi telur udang dalam ruang pengeraman telur berkisar antara 19 hari, apabila telur udang menetas sebelum mencapai air payau maka larva tersebut akan mati sebelum berumur 3-4 hari (Ling \& Merican,1961 dalam Hadie \& Hadie,1993). Perairan Sekayu dan Rawas jauh dari kuala sungai yang berair payau, jaraknya lebih dari $100 \mathrm{~km}$ sehingga besar kemungkinan telur sudah menetas sebelum induk udang galah mencapai air payau. Untuk itu penyelamatan induk udang galah yang sudah dibuahi
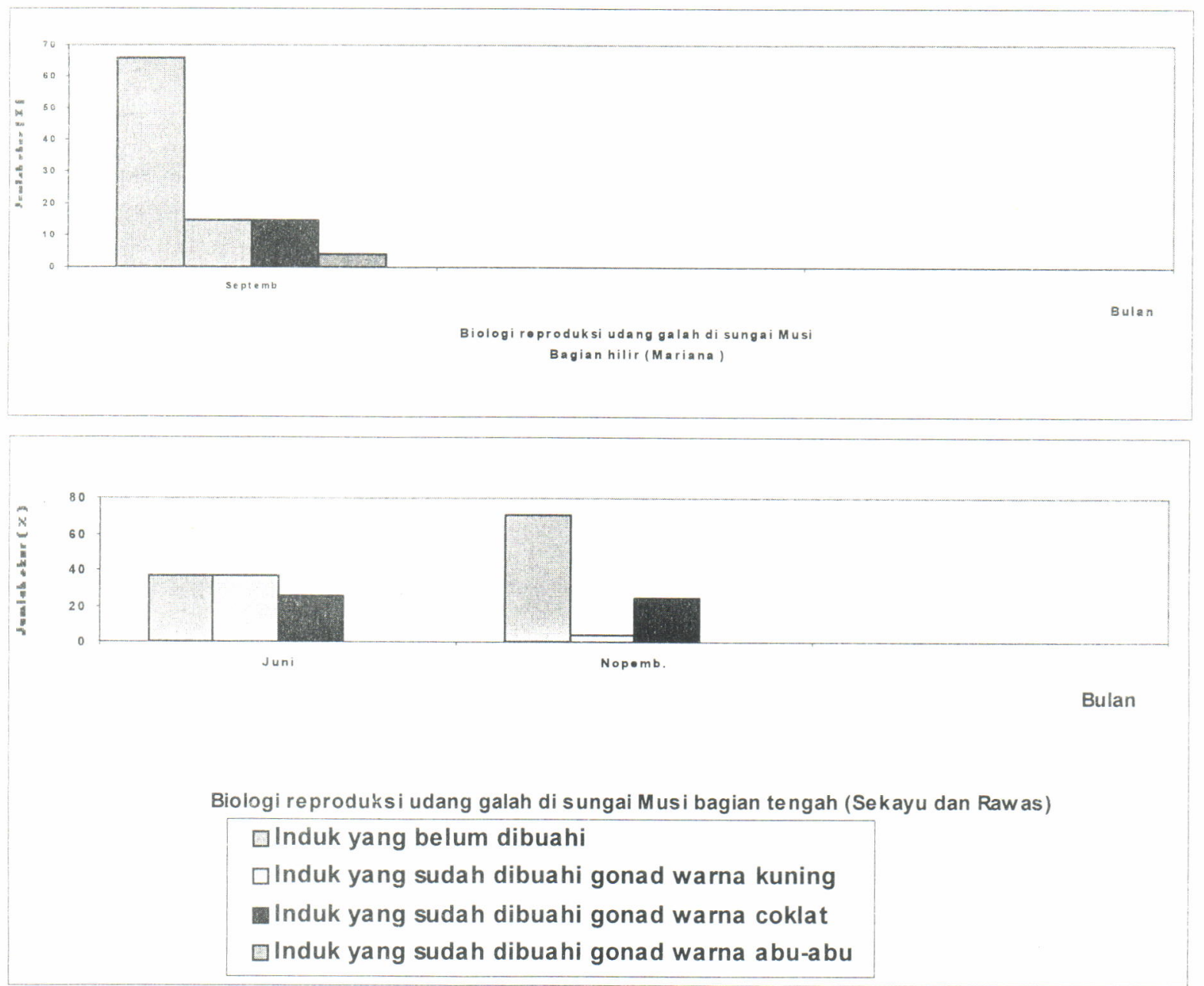

Gambar 2. Biologi reproduksi udang galah (Macrobrachium rosenbergii) di sungai Musi Sumatera Selatan 
dapat dilakukan dengan cara menetaskan secara insitu, kemudian larvanya ditebar ke perairan umum.

Di bagian hulu sungai (stasiun pengamatan: Muara Lakitan dan Tebing Tinggi) sulit mendapatkan sampel udang galah, bahkan di Tebing tinggi menurut informasi masyarakat tidak pernah tertangkap udang galah. Hal tersebut merupakan indikasi bahwa bagian hulu sungai yang berarus deras dan berbatu serta tidak terdapat daerah rawa banjiran maupun rawa pasang surut bukan merupakan habitat udang galah. Habitat pemijahan udang galah adalah perairan yang banyak terdapat hutan rawa banjiran, sedangkan habitat penetasan udang galah adalah perairan yang dipengaruhi pasang surut air laut.

Berdasarkan pengambilan contoh gonad menunjukkan bahwa udang galah dapat memijah sepanjang tahun tanpa mengenal musim, namun pada saat musim kemarau di bagian tengah dan hulu sungai banyak mengalami kekeringan sehingga sampel udang galah tidak banyak didapatkan.

\section{Fekunditas}

Jumlah telur sangat tergantung dari ukuran udang galah, makin besar udang galah mempunyai fekunditas yang lebih banyak daripada yang berukuran kecil. Berdasarkan pengamatan di laboratorium udang yang berukuran $15 \mathrm{~cm}-29 \mathrm{~cm}$ mempunyai fekunditas 28.000 butir-59.000 butir. Diameter telur udang sangat tergantung tingkat kematangan gonad. Gonad berwarna kuning jingga (baru dibuahi) frekuensi yang terbanyak pada diameter 0,25 mm-0,75 mm, yang berwarna coklat frekuensi yang terbanyak pada diameter $1,00 \mathrm{~mm}-$ $1,50 \mathrm{~mm}$, sedangkan yang berwarna abu-abu (hampir menetes) frekuensi yang terbanyak pada diameter $1,25 \mathrm{~mm}-1,75 \mathrm{~mm}$ (tabel 1).

Tabel 1. Fekunditas udang galah (M. rosenbergii) di Sungai Musi Sumatera Selatan

\begin{tabular}{|c|c|c|}
\hline Ukuran udang dan warna gonad & $\begin{array}{l}\text { Diameter telur } \\
(\mathrm{mm})\end{array}$ & $\begin{array}{l}\text { Jumlah telur } \\
\text { (butir) }\end{array}$ \\
\hline \multirow{8}{*}{$\begin{array}{l}\text { 1. Panjang total }=15,7 \mathrm{~cm} \\
\text { Warna telur }=\text { kuning jingga }\end{array}$} & $0,25-0,50$ & 14.420 \\
\hline & $0,50-0,75$ & 14.280 \\
\hline & $0,75-1,00$ & 0 \\
\hline & $1,00-1,25$ & 0 \\
\hline & $1,25-1,50$ & 0 \\
\hline & $1,50-1,75$ & 0 \\
\hline & $1,75-2,00$ & 0 \\
\hline & & Jumlah $=28.700$ \\
\hline \multirow{9}{*}{$\begin{array}{l}\text { 2. Panjang total }=29,5 \mathrm{~cm} \\
\text { Warna telur }=\text { coklat }\end{array}$} & $0,25-0,50$ & \\
\hline & $0,50-0,75$ & \\
\hline & $0,75-1,00$ & 7.050 \\
\hline & $1,00-1,25$ & 23.300 \\
\hline & $1,25-1,50$ & 29.375 \\
\hline & $1,50-1,75$ & 0 \\
\hline & $1,75-2,00$ & \\
\hline & $2,00-2,25$ & 0 \\
\hline & & Jumlah $=59.725$ \\
\hline \multirow{8}{*}{$\begin{array}{l}\text { 3. Panjang total }=16,4 \mathrm{~cm} \\
\text { Warna telur }=\text { abu-abu }\end{array}$} & $0,25-0,50$ & 0 \\
\hline & $0,50-0,75$ & 0 \\
\hline & $0,75-1,00$ & 670 \\
\hline & $1,00-1,25$ & 3.020 \\
\hline & $1,25-1,50$ & 28.840 \\
\hline & $1,50-1,75$ & 24.820 \\
\hline & $1,75-2,00$ & 2.015 \\
\hline & & Jumlah $=59.365$ \\
\hline
\end{tabular}

\section{Hasil Tangkapan}

Alat tangkap yang sering digunakan untuk menangkap udang galah yaitu belat (set net), Empang (Barrier Traps), Corong/Tuguk (Filtering Divice), Sengkirai (Pot Traps), Jala (Cash net), dan Pancing (Hook). Kegiatan penangkapan udang galah di bagian hilir sungai tidak mengenal musim alat yang digunakan yaitu Belat, stroom, pancing, dan jala.
Sedangkan di bagian tengah sungai yang banyak didominasi habitat rawa banjiran, musim penangkapan udang galah dilakukan pada saat awal sampai dengan akhir musim penghujan.

Saat musim kemarau sulit didapatkan udang galah, alat tangkap yang besar seperti corong dan tuguk tidak dapat menangkap udang galah. Penangkapan hanya terbatas oleh beberapa jenis alat 
seperti pancing dan jala. Sedangkan di bagian hulu sungai baik di musim penghujan maupun kemarau sulit didapatkan udang galah.

Hasil percobaan penangkapan dengan alat tangkap belat, yang dilakukan pada bulan Juni hingga Nopember 2002 menunjukkan bahwa di bagian hilir sungai hasil tangkapan per hari lebih tinggi daripada di bagian tengah sungai, sedangkan di bagian hulu sungai alat tangkap tersebut tidak beroperasi karena tidak mendapatkan hasil. Hal tersebut merupakan indikasi bahwa pada saat itu sediaan (stok) udang galah di bagian hilir lebih tinggi.

Hasil tangkapan udang galah per hari dengan alat tangkap belat di bagian hilir sungai yang dilakukan mulai bulan Juni hingga Nopember menunjukkan penurunan. Hal tersebut disebabkan udang galah sudah mulai bergerak ke arah hulu sungai. Hasil tangkapan belat pada masing-masing stasiun di bagian hilir sungai berbeda, lebih ke arah hilir hasilnya cenderung lebih tinggi (tabel 2,3, dan 4). Sedangkan alat tangkap belat di bagian tengah (stasiun Sekayu) baru dapat dioperasikan pada bulan September, untuk menangkap udang galah yang beruaya dari hilir, namun hasilnya masih sangat kecil.

Di stasiun pengamatan Rawas penangkapan udang tidak menggunakan belat tetapi hanya dengan alat yang sederhana seperti sengkirai (jenis bubu). Berdasarkan catatan responden hasil tangkapan ratarata satu orang nelayan dengan mengoperasikan Sengkirai sebanyak 25 buah per hari adalah $0,62 \mathrm{~kg}$ pada bulan Nopember dan $1,57 \mathrm{~kg}$ pada bulan Desember (tabel 5). Sedangkan di bagian hilir (Mariana) dengan jumlah alat yang sama yaitu 25 buah mendapatkan hasil rata-rata $0,58 \mathrm{~kg}$ per hari pada bulan Nopember dan $0,53 \mathrm{~kg}$ per hari untuk bulan Desember. Alat tangkap Sengkirai tidak dapat menangkap udang yang berukuran kecil, maka di bagian hilir Sungai Musi hasil tangkapannya sengkirai tidak banyak karena di daerah ini banyak udang yang berukuran kecil. Sedangkan di zona tengah, udang berukuran besar lehih banyak sehingga hasil tangkapan alat sengkirai lebih banyak. Hasil tangkapan sengkirai tertinggi terjadi pada bulan Desember karena saat itu air banjir udang yang berukuran besar mulai beruara ke hutan rawa untuk memijah sehingga mudah ditangkap oleh sengkirai.

Tabel 2. Hasil tangkapan udang galah ( $M$. rosenbergii) per hari oleh alat tangkap Belat (Set net) di Makati Sungai Musi Sumatera Selatan

\begin{tabular}{|c|c|c|c|}
\hline Juni (kg) & Juli (kg) & Agustus (kg) & September (kg) \\
\hline 10 & 1,5 & 4 & 5 \\
\hline 4 & 4 & 2 & 3,5 \\
\hline 7 & 6 & 5 & 7 \\
\hline 6 & 3 & 2,5 & 4 \\
\hline 4 & 2 & 4 & 6 \\
\hline 4 & 2,5 & 3 & 8 \\
\hline 3 & 3 & 1 & 4 \\
\hline 3 & 2 & 3 & 2 \\
\hline 4 & & 2 & 3 \\
\hline 5 & & 3 & 5 \\
\hline 3 & & 5 & 4 \\
\hline 5 & & 3 & 3 \\
\hline 4 & & 1 & 5 \\
\hline \multirow[t]{3}{*}{3} & & 3 & \\
\hline & & 2 & \\
\hline & & 4 & \\
\hline$X=4,64$ & $x=3$ & 3,00 & 4,57 \\
\hline $\operatorname{Max}=10$ & $\operatorname{Max}=6$ & 5 & 8 \\
\hline Min $=3$ & $\operatorname{Min}=1,5$ & 1 & 2 \\
\hline
\end{tabular}

Keterangan: Makati merupakan stasiun pengamatan pertama hasil tangkapan Belat paling hilir 
Tabel 3. Hasil tangkapan udang galah ( $M$. rosenbergii) per hari dengan alat tangkap Belat (Set net) di Mariana Sungai Musi Sumatera Selatan

\begin{tabular}{|c|c|c|c|c|}
\hline Juni (kg) & Juli (kg) & Agustus (kg) & September (kg) & Nopember (kg) \\
\hline 1,5 & 2 & 2,3 & 3,75 & 1 \\
\hline 2 & 1,5 & 1,75 & 2,5 & 0,9 \\
\hline 2 & 1 & 1,9 & 2,1 & 0,7 \\
\hline 3,5 & 2,5 & 4 & 1,3 & 1 \\
\hline 2 & 1,5 & 3,5 & 5 & 1,5 \\
\hline 3,5 & 2,8 & 3,5 & 1,7 & 1,5 \\
\hline 2 & 3,2 & 2 & 1,1 & \\
\hline 3 & 2,8 & 3 & 1,5 & \\
\hline 3 & 5 & 3,4 & 1,8 & \\
\hline 5,7 & 4,5 & 4,5 & 2 & \\
\hline 6 & 5 & 0,6 & 0,8 & \\
\hline 5,3 & 5,5 & 3,7 & 1 & \\
\hline 4,5 & 4,5 & 3,9 & 1,3 & \\
\hline 3,5 & 1,1 & 3,75 & 2,7 & \\
\hline 4,5 & 6 & 2,5 & 1,35 & \\
\hline 4,5 & 3,5 & 1,3 & 1,5 & \\
\hline \multirow[t]{10}{*}{11} & 4,5 & 2,3 & 2 & \\
\hline & 5,5 & 1,7 & 1,5 & \\
\hline & 6,5 & 2,8 & 0,9 & \\
\hline & 4,5 & 7,7 & 1,4 & \\
\hline & 4,75 & 10,5 & 1 & \\
\hline & 3,95 & 5,5 & & \\
\hline & 2,35 & 4 & & \\
\hline & 3,6 & 4,5 & & \\
\hline & 4,4 & & & \\
\hline & 1,6 & & & \\
\hline$x=5,6$ & $x=3,61$ & $X=3,74$ & $X=1,48$ & $X=1,1$ \\
\hline $\operatorname{Max}=11$ & $\operatorname{Max}=6,5$ & $\operatorname{Max}=10,5$ & $\operatorname{Max}=2,7$ & $\operatorname{Max}=1,5$ \\
\hline Min=3,5 & $\operatorname{Min}=1$ & $\operatorname{Min}=0,6$ & $\operatorname{Min}=0,8$ & Min $=0,7$ \\
\hline
\end{tabular}

Keterangan: Mariana merupakan stasiun pengamatan kedua hasil tangkapan dengan alat tangkap Belat pada zona hilir sungai

Tabel 4. Hasil tangkapan udang galah ( $M$. rosenbergii) per hari oleh alat tangkap Belat (Set net) di Gandus dan Sekayu Sungai Musi Sumatera Selatan

\begin{tabular}{cccc}
\hline & Stasiun Gandus & Stasiun Sekayu \\
\hline Juni (kg) & Juli (kg) & Agustus (kg) & September (kg) \\
\hline 1,6 & 1,8 & 2,5 & 1,25 \\
0,9 & 1,3 & 1,5 & 0,8 \\
0,6 & 1,3 & 1,3 & 0,35 \\
1,5 & 0,9 & 1,1 & 0,25 \\
3 & & 1,6 & 0,45 \\
& & & 0,3 \\
& & & 1,5 \\
\hline$X=1,54$ & $X=1,32$ & $X=1,6$ & $X=0,7$ \\
\hline Max=3 & Max=1,8 & Max=2,5 & Max=1,5 \\
\hline Min=0,6 & Min=0,9 & Min=1,1 & Min $=0,25$ \\
\hline
\end{tabular}

Keterangan:

- Gandus merupakan stasiun ketiga pengamatan hasil tangkapan dengan alat Belat pada zona hilir sungai

- Stasiun Sekayu merupakan stasiun pertama pada zona tengah sungai 
Tabel 5. Hasil tangkapan udang galah ( $M$. rosenbergii) per hari dengan alat tangkap Sengkirai (Pot traps) di perairan Mariana dan Muara Rawas Sungai Musi Sumatera Selatan

\begin{tabular}{|c|c|c|c|c|}
\hline \multicolumn{3}{|c|}{ Muara Rawas } & \multicolumn{2}{|c|}{ Mariana } \\
\hline September (kg) & Nopember (kg) & Desember (kg) & Nopember (kg) & Desember $(\mathbf{k g})$ \\
\hline 0,1 & 0,5 & 2,9 & 0,5 & 0,7 \\
\hline 0,5 & 0,8 & 1,3 & 0,4 & 0,5 \\
\hline 0,4 & 0,5 & 1,5 & 0,7 & 0,5 \\
\hline 0,8 & 0,8 & 0,6 & 0,8 & 0,6 \\
\hline 0,2 & 0,5 & & 0,5 & 0,7 \\
\hline 0,1 & 0,8 & & & 0,7 \\
\hline 0,3 & 0,7 & & & 0,9 \\
\hline 0,5 & 0,6 & & & \\
\hline 0,3 & 0,4 & & & \\
\hline \multicolumn{5}{|l|}{0,1} \\
\hline \multicolumn{5}{|l|}{0,4} \\
\hline \multicolumn{5}{|l|}{0,5} \\
\hline$X=0,35$ & $X=0,62$ & $X=1,57$ & $X=0,58$ & $X=0,53$ \\
\hline $\operatorname{Max}=0,8$ & $\operatorname{Max}=0,8$ & $\operatorname{Max}=2,9$ & $\operatorname{Max}=0,8$ & $\operatorname{Max}=0,7$ \\
\hline Min $=0,1$ & Min $=0,4$ & $\operatorname{Min}=0,6$ & Min $=0,4$ & $\operatorname{Min}=0,5$ \\
\hline
\end{tabular}

Keterangan: Hasil tangkapan dengan jumlah alat sengkirai 25 buah

\section{Kualitas Air}

Bagian hilir sungai salinitasnya relatif lebih tinggi daripada bagian tengah dan hulu sungai. Berdasarkan pengamatan kualitas air di daerah Sungsang pada saat siang, sore, malam, dan pagi hari menunjukkan bahwa parameter kualitas air sangat berfluktuasi terutama salinitas. Salinitas tertinggi pada saat terkena air pasang tertinggi pada jam $22 .{ }^{30}$ yaitu $22 \%$ dan terendah pada jam $14 .^{\circ 0}$ yaitu $2,5^{\circ}$. 0 . Air payau merupakan media yang baik bagi penetasan telur dan perawatan larva udang galah (Djadjadiradja et. al., 1980; Hadie \& Hadie, 1993; Utomo, 2001). Sehingga di bagian hilir terdapat udang galah berbagai macam ukuran dan tingkat kematangan gonad. Conductivity di bagian hilir sungai relatif lebih tinggi daripada bagian tengah dan hulu sungai, kisaran nilai conductivity mulai dari perairan Mariana, Makati, dan Sungsang yaitu: $330 \mu S-20.000 \mu S$. Hal tersebut berkaitan dengan nilai salinitas yang tinggi yang akan menyebabkan ion elektrolit (DHL) lebih tinggi.

Bagian tengah yaitu di stasiun pengamatan Sekayu dan Rawas nilai pH (6-7) dan conductivity
(50-80 $\mu$ S) relatif lebih rendah daripada di bagian hilir dan hulu (tabel 6). Hal tersebut disebabkan karena pengaruh daerah rawa banjiran yang banyak mengandung serasah mengalami dekomposisi sehingga perairan rawa banjiran menjadi asam. Namun pada zona tengah ini banyak terdapat detritus yang menjadi pakan alami udang galah. Hutan rawa yang terdapat pada zona ini juga merupakan habitat yang baik bagi pemijahan udang galah.

Kondisi di bagian hulu sungai kondisi perairannya tidak ada daerah rawa dan arus airnya lebih cepat. Berdasarkan pengamatan kualitas air di stasiun Tebing Tinggi menunjukkan bahwa oksigen terlarut lebih tinggi daripada di bagian tengah dan hilir. Hal tersebut disebabkan arus air yang deras akan meningkatkan difusi oksigen dari udara. Di samping itu zona ini tidak berawa sehingga tidak ada reduksi oksigen yang digunakan dalam proses dekomposisi di perairan rawa. Tidak ada perairan rawa di zona ini juga berarti detritus yang menjadi makanan udang galah juga sedikit. Sedikit hutan rawa berarti daerah pemijahan udang galah berkurang, sehingga di perairan hulu sungai sulit ditemukan udang galah. 
Tabel 6. Parameter kimia dan fisika air di Sungai Musi Sumatera Selatan

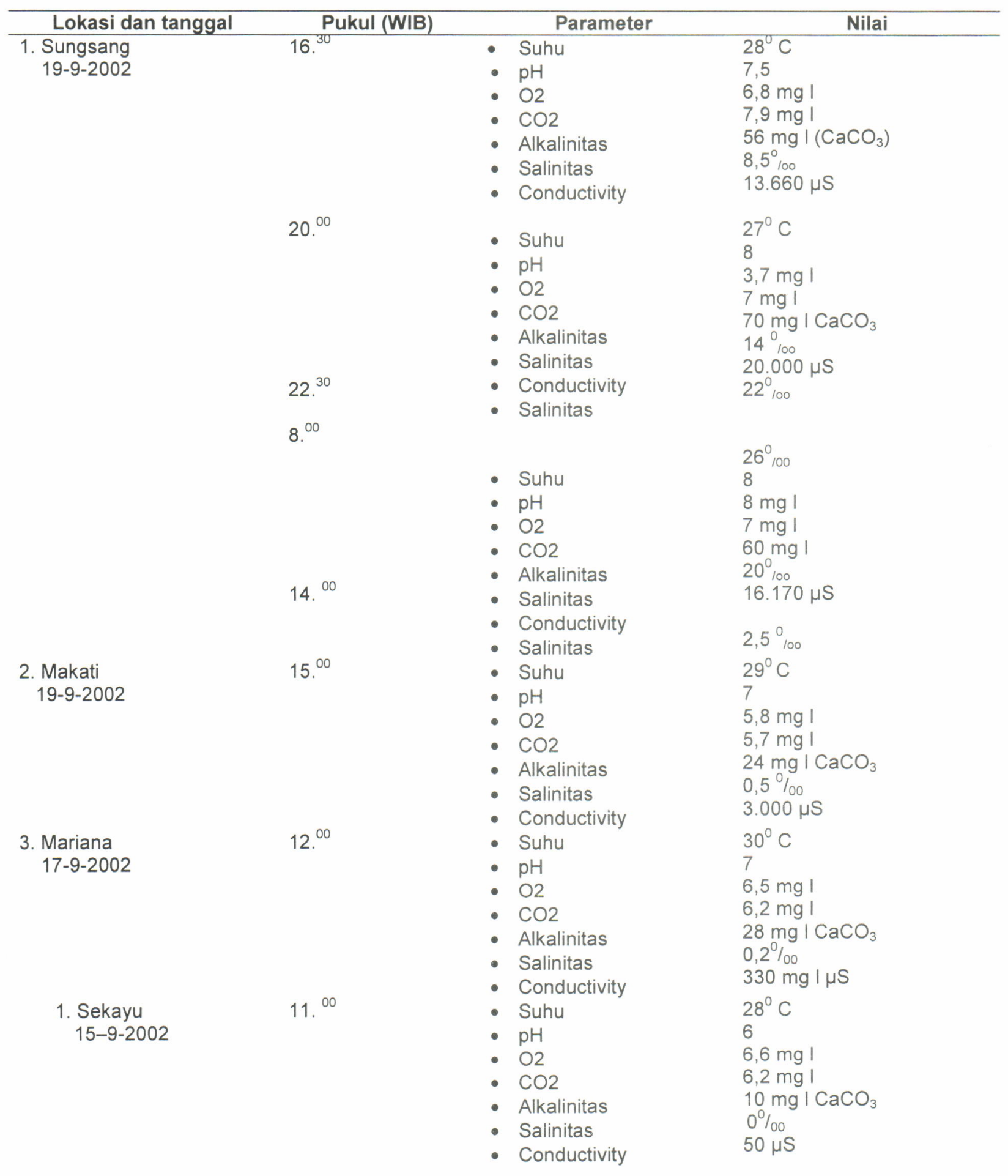




\begin{tabular}{|c|c|c|c|}
\hline $\begin{array}{l}\text { 2. Muara Rawas } \\
14-9-2002\end{array}$ & $11 .^{00}$ & $\begin{array}{l}\text { - Suhu } \\
\text { - } \mathrm{pH} \\
\text { - } \mathrm{O} 2 \\
\text { - } \mathrm{CO} 2 \\
\text { - Alkalinitas } \\
\text { - Salinitas } \\
\text { - Conductivity }\end{array}$ & $\begin{array}{l}28^{\circ} \mathrm{C} \\
7 \\
7,2 \mathrm{mg} \mathrm{I} \\
7,4 \mathrm{mg} \text { I } \\
20 \mathrm{mg} \mathrm{I} \\
0 \% \\
83 \mu \mathrm{S}\end{array}$ \\
\hline $\begin{array}{l}\text { 3. Tebing Tinggi } \\
4-11-2002\end{array}$ & $17 .^{00}$ & $\begin{array}{l}\text { - } \text { Suhu } \\
\text { - } \mathrm{pH} \\
\text { - } \mathrm{O} 2 \\
\text { - } \mathrm{CO} 2 \\
\text { - } \text { Alkalinitas } \\
\text { - Salinitas } \\
\text { - Conductivity }\end{array}$ & $\begin{array}{l}29^{\circ} \mathrm{C} \\
7 \\
8,9 \mathrm{mg} \mid \\
- \\
43 \\
0 \% \\
150 \mu \mathrm{S}\end{array}$ \\
\hline
\end{tabular}

\section{KESIMPULAN DAN SARAN}

\section{Kesimpulan}

1. Ada perbedaan distribusi udang galah berdasarkan ukuran udang di Sungai Musi.

- Zona hilir sungai terdapat berbagai macam ukuran dengan kisaran panjang total $5 \mathrm{~cm}-30$ $\mathrm{cm}$, yang didominasi oleh ukuran $5 \mathrm{~cm}-10 \mathrm{~cm}$, setiap saat ukuran tersebut selalu ada.

- Zona bagian tengah di stasiun Sekayu pada bulan Juni didominasi oleh ukuran $15 \mathrm{~cm}-20$ $\mathrm{cm}$, sedangkan pada bulan September ukuran yang mendominasi $10 \mathrm{~cm}$ bahkan ada ukuran 5 $\mathrm{cm}$ walaupun jumlahnya tidak banyak. $\mathrm{Di}$ stasiun kedua zona bagian tengah yaitu muara Rawas didominasi oleh ukuran $20 \mathrm{~cm}-25 \mathrm{~cm}$, pada bulan Nopember ada ukuran $10 \mathrm{~cm}$ walaupun jumlahnya tidak banyak.

- Zona bagian hulu sungai yaitu di Tebing Tinggi jarang ditemukan udang galah, kadang-kadang ada namun ukurannya diatas $25 \mathrm{~cm}$.

2. Ada perbedaan distribusi induk udang galah berdasarkan gonad yang sudah dibuahi:

- Zona bagian hilir Sungai Musi terdapat berbagai macam tingkat kematangan gonad yang sudah dibuahi yaitu warna kuning pertanda baru memijah, selanjutnya warna coklat dan warna abu-abu pertanda sudah hampir menetas.

- Zona bagian tengah di stasiun sekayu terdapat induk udang galah yang sudah dibuahi dengan didominasi warna kuning dan coklat, warna abu-abu jarang dijumpai.

Udang galah dapat memijah sepanjang tahun, fekunditas individu pada ukuran $15 \mathrm{~cm}-30 \mathrm{~cm}$ berkisar antara 28.700-59.700 butir telur.

\section{Saran}

1. Jalur ruaya udang galah sepanjang sungai harus lancar, karena siklus hidupnya memerlukan habitat yang luas dari hilir sampai ke hulu sungai.

2. Perlu adanya pemanfaatan induk udang galah yang sudah dibuahi di badan air yang jauh dari kuala sungai untuk ditetaskan secara insitu, kemudian ditebar di perairan umum.

\section{UCAPAN TERIMA KASIH}

Peneliti mengucapkan terima kasih kepada para nelayan responden antara lain yaitu Bapak Jum'at di Makati, Bapak Arbain di Mariana, Bapak Somad di Mariana, Bapak Fachrozi di Sekayu, dan Bapak Robinson di Muara Rawas yang telah banyak membantu dalam pelaksanaan penelitian di lapangan.

\section{DAFTAR PUSTAKA}

Arifin, Z. 1978. Beberapa aspek tentang penangkapan ikan di perairan Lubuk Lampam Sumatera Selatan. Disampaikan dalam Simposium Modernisasi Perikanan Rakyat di Jakarta tanggal 27-30 Juni 1978. LPPD Cabang Palembang. 25 hal.

Djajadiredja, R. H. Hadidjaja \& A. Ismail. 1980. Pembenihan udang galah ( $M$. Rosenbergii) skala kecil. LPPD Bogor. 43 hal

Effendie, M. I. 1997. Biologi Perikanan. Yayasan Pustaka Nusantara. Yogyakarta. 155 hal.

Hadie, W. \& L. E. Hadie. 1993. Pembenihan udang galah (Macrobrachium rosenbergii). Kanasius. Yogyakarta. 110 hal. 
Hoggarth, D. \& A. D, Utomo. 1994. The fisheries ecology of Lubuk Lampam River floodplain in South Sumatera. International Journal Fisheries Research Elsevier. Netherland 20: 191-213.

Mantel, L. H. 1983. The biology of crusteacea, internal anatomy and physiologica! regulation. Academic Press. New York. 5: 1-26.
Utomo, A. D. 1997. Perikanan udang galah ( $M$ rosenvbergii) di Sungai Lempuing Sumatera Selatan (Unpublished). Lolitkanwar. Palembang 16 hal.

Utomo, .A. D. 2001. Ruaya dan pertumbuhan udang galah ( $M$. rosenbergii) di Sungai Lempuing Sumatera Selatan (Tesis). Program Pascasarjana IPB. Bogor. 78 hal.
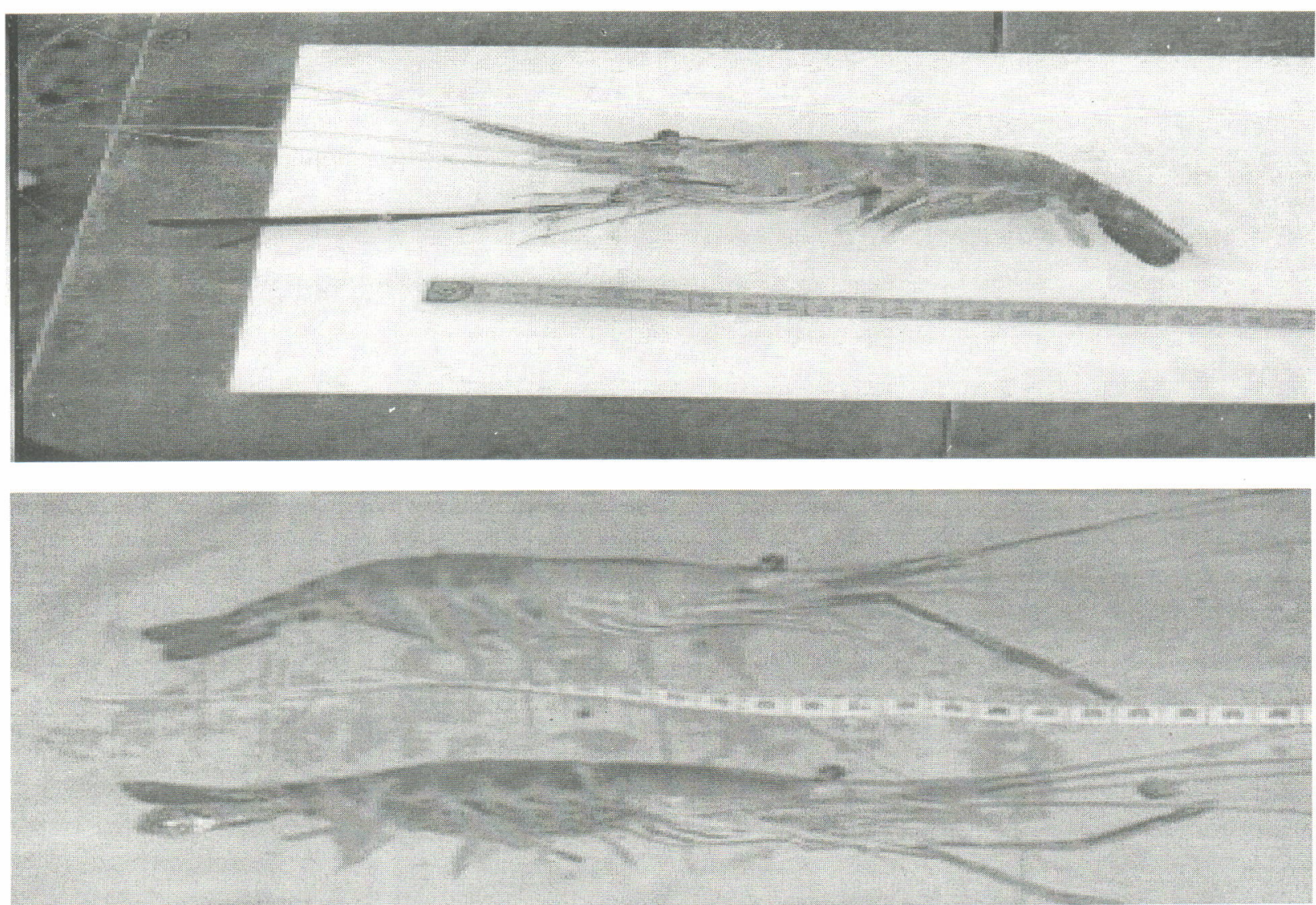

Lampiran 1. Foto gonad udang galah (Macrobrachium rosenbergii) yang sudah dibuahi. 